УДК 159.923 .32

DOI https://doi.org/10.26661/2310-4368/2021-1-10

\title{
ОСОБЛИВОСТІ ВІДПОВІДАЛЬНОСТІ ЯК СВІТОГЛЯДНОГО ФЕНОМЕНУ СТУДЕНТІВ-ПСИХОЛОГІВ І СОЦІАЛЬНИХ ПРАЦІВНИКІВ НА ПЕРВИННОМУ ЕТАПІ ПРОФЕСІЙНОЇ ПІДГОТОВКИ
}

\author{
Кутішенко В. П. \\ кандидат психологічних наук, дочент, \\ доцент кафедри психології особистості та соціальних практик \\ Інститут людини \\ Киїського університету імені Бориса Грінченка \\ бульв. І. Шамо, 18/2, Київ, Україна \\ orcid.org/0000-0002-5597-705X \\ v.kutishenko@kubg.edu.ua \\ Патинок О. П. \\ кандидат психологічних наук, дочент, \\ професор кафедри сочіальної політики \\ факультету сочіально-економічної освіти \\ Начіональний педагогічний університет імені М. П. Драгоманова \\ вул. Пирогова, 9, Київ, Украӥна \\ orcid.org/0000-0002-5597-705X \\ o.p.patynok@npu.edu.ua \\ Ставицька С. O. \\ доктор психологічних наук, професор, \\ завідувач кафедри загальної і сочіальної психологї та психотерапії \\ Національний педагогічний університет імені М. П. Драгоманова \\ вул. Пирогова, 9, Київ, Украӥна \\ orcid.org/0000-0003-0800-0876 \\ stavics@ukr.net
}

Вінник Н. Д.

кандидат психологічних наук, старший науковий співробітник, старший викладач кафедри психологї особистості та соціальних практик

Інститут людини

Київського університету імені Бориса Грінченка

бульв. І. Шамо, 18/2, Київ, Україна

orcid.org/0000-0002-2593-2088

n.vinnyk@kubg.edu.ua

\footnotetext{
Ключові слова: студентипериокурсники, види відповідальності, мотиви відповідальної поведінки, вольові якості особистості, лідерські особистісні
}

У статті висвітлено результати дослідження особливостей усвідомлення
майбутніми психологами та соціальними працівниками феномену
відповідальності, мотивів власної відповідальної поведінки, видів
відповідальності, а також найбільш значущих сфер іï реалізації. Вихідним
положенням дослідження стало розуміння відповідальності як базової
світоглядної властивості особистості, що є результатом інтеграції іiі 
властивості, прагматична спрямованість, духовний розвиток, совість, обов'язок, самореалізація, моральне самоствердження. суб'єктивного уявлення про світ і соціальну взаємодію, осмислення себе в цьому світі та усвідомлення себе як творця власної поведінки, що виявляється в різних системах життєдіяльності.

Встановлено, що у першокурсників домінуючим $\epsilon$ розуміння відповідальності як вміння особистості передбачати наслідки вчинків та усвідомлювати їх значущість, свідоме прийняття та виконання обов'язків, здатність дотримуватися норм і доводити справу до кінця. Здебільшого вони пов'язують відповідальність із вольовими і лідерськими характеристиками особистості, здатністю критично мислити. Значно менша їх частина пов'язує відповідальність із моральністю, внутрішніми потребами, совістю і духовним розвитком особистості.

Констатовано, що у майбутніх психологів більш виражені мотиви самореалізації, самопізнання та прагматичні мотиви, ау майбутніх соціальних працівників - мотиви спілкування та морального самоствердження. Для майбутніх психологів найбільш значущою сферою відповідальності $\epsilon$ система «Я-Я», що акцентує увагу на відповідальності як самореалізації, самопізнанні та прагматичній спрямованості, а для соціальних працівників це система взаємодії «Я-Інші» як спосіб їх реалізації у майбутній професійній діяльності. Це зумовлено віковими й соціально-психологічними особливостями студентів першого курсу загалом і специфікою особистісних характеристик абітурієнтів, які обирають професію психолога чи соціального працівника, а також особливостями процесу їх професійної підготовки у закладах вищої освіти.

Отримані результати зумовлюють необхідність формування у студентів світоглядних орієнтирів на усвідомленість духовного виміру власного життя та розвиток духовних цінностей як основних регуляторів власної поведінки.

\title{
FEATURES OF RESPONSIBILITY AS A WORLDVIEW PHENOMENON OF PSYCHOLOGY STUDENTS AND SOCIAL WORKERS AT THE INITIAL STAGE OF THE PROFESSIONAL TRAINING
}

\author{
Kutishenko V. P. \\ Candidate of Psychological Sciences, Associate Professor, \\ Senior Lecturer at the Department of Psychology of Personality and Social Practices \\ Institute of Human Sciences \\ of Borys Grinchenko Kyiv University \\ Ihor Shamo blvd, 18/2, Kyiv, Ukraine \\ orcid.org/0000-0002-5597-705X \\ v.kutishenko@kubg.edu.ua \\ Patynok O. P. \\ Candidate of Psychological Sciences, Professor, \\ Professor at the Department of Social Policy \\ National Pedagogical Dragomanov University \\ Pirohova str., 9, Kyiv, Ukraine \\ orcid.org/0000-0001-8096-3584 \\ o.p.patynok@npu.edu.ua
}




\author{
Stavytska S. O. \\ Doctor of Psychological Sciences, Professor, \\ Head of the Department of General and Social Psychology and Psychotherapy \\ National Pedagogical Dragomanov University \\ Pirohova str., 9, Kyiv, Ukraine \\ orcid.org/0000-0003-0800-0876 \\ stavics@ukr.net
}

Vinnyk N. D.

Candidate of Psychological Sciences, Senior Researcher,

Assistant Professor at the Department of Psychology of Personality and Social Practices

Institute of Human Sciences

of Borys Grinchenko Kyiv University

Ihor Shamo blvd, 18/2, Kyiv, Ukraine

orcid.org/0000-0002-2593-2088

n.vinnyk@kubg.edu.ua

Key words: first-year students, responsibility types, motives for responsible behavior, volitional qualities of personality, leadership personality traits, pragmatic orientation, spiritual development, conscience, conscience, selfactualization, moral self-esteem.
The article covers findings of the study of features of consciousness of the responsibility phenomenon by the future psychologists and social workers, motives for one's responsible behavior, types of responsibility and the most significant areas for its implementation. A departure position of the study involves understanding of responsibility as a basic worldview quality of personality, which a result of the integration of his subjective vision of the world and social interaction, selfawareness in this world and realizing oneself as a creator of one's own behavior manifesting in various systems of life.

It is established that the understanding of responsibility as an individual's ability to predict consequences of actions and awareness of their significance, conscious acceptance and fulfillment of responsibilities, ability to adhere to rules and finish the job is dominant among first-year students. They mainly associate responsibility with volitional and leadership characteristics of an individual, the ability to think critically. A much smaller part of them associates responsibility with morality, internal needs, conscience and spiritual development of personality.

The authors state the future psychologists have more pronounced motives for selfactualization, self-knowledge and pragmatic motives, and future social workers motives for communication and moral self-esteem. The self-self-system that focuses on the responsibility as self-actualization, self-cognition and pragmatic orientation is the most important field for the future psychologists, the Self-Others interaction system as a way of their fulfilment in the future professional activity - for social workers. The above is caused by the age and socio-psychological characteristics of first-year students in general and the specifics of personal characteristics of applicants, who choose the profession of psychologist or social worker, as well as by the peculiarities of their training in higher education institutions.

The findings necessitate the formation of students' worldview focuses on the awareness of the spiritual dimension of their own lives and the development of spiritual values as the basic regulators of their behavior.
Постановка проблеми. У період глобальних перетворень: змін клімату, пандемії (COVID), гібридних війн, людство намагається віднайти шляхи виходу із ситуації, що склалася. Конструктивне подолання сьогоднішніх і майбутніх нега- раздів вимагає адекватного розуміння причин цих негативних явищ, наявності чітких орієнтирів їх усунення та усвідомлення особистістю власної причетності до вказаних подій і можливих прогресивних зрушень у їх вирішенні. Саме тому фор- 
мування відповідальності майбутнього фахівця повинно стати одним із пріоритетних навчальних, виховних і розвиваючих завдань при роботі зі студентами у закладах вищої освіти. Адже високий рівень відповідальності особистості стане запорукою їі спроможності успішно вибудовувати стосунки з іншими людьми, світом і самим собою на засадах загальнолюдських духовних цінностей, які виступають засобом досягнення індивідуальної та групової соціально-психологічної стабільності і сприяють формуванню здатності особистості жити по совісті.

Особливо важливою та усвідомленою, на нашу думку, має бути така позиція у фаховій діяльності працівників психологічних і соціальних служб, діяльність яких насамперед спрямована на пізнання іншої людини та надання їй допомоги у вирішенні різного роду психологічних і життєвих проблем. Це й зумовило наш інтерес до розгляду проблеми відповідальності на первинному етапі підготовки майбутніх психологів і соціальних працівників у закладах вищої освіти.

Проблема різних виявів і становлення відповідальності була предметом вивчення як вітчизняних (С. Баранова [1], Т. Гурлєва [2], О. Палагнюк [3], О. Патинок [4], М. Савчин [5] та інші), так і зарубіжних науковців (А. Маслоу [6], К. Муздибаєв [7], Ф. Перлз [8], К. Роджерс [9], К. Helkam [10] та інші). Однак аналіз наукових розробок iз вказаної проблеми засвідчив брак системних досліджень особливостей становлення відповідальності як світоглядного феномену майбутніх психологів і соціальних працівників у процесі їх фахової підготовки.

Мета статті: висвітлити результати дослідження особливостей відповідальності майбутніх психологів і соціальних працівників як їх світоглядного утворення, зокрема, розкрити особливості усвідомлення ними феномену відповідальності та мотивів власної відповідальної поведінки, а також найбільш значущих сфер ії реалізації.

Виклад основного матеріалу дослідження. Теоретичною основою дослідження відповідальності як світоглядного утворення особистості стала наукова позиції Б. Ананьєва, який пропонує розглядати глибинні проблеми особистості через вивчення її сутнісного ядра, яким $є$ суперечність між інтимністю (внутрішнім світом) людини та суспільно прийнятним (зовнішнім) світом [11].

У цьому контексті влучним $\epsilon$ визначення відповідальності, запропоноване К. Абульхановою-Славською, яка розглядає цей феномен як прагнення і реальне забезпечення суб'єктом цілісності, самостійності і успішності його функціонування у соціальному (міжособистісному та внутрішньогруповому) просторі діяльності. При цьому досягнення результату гарантується самою особистістю, яка взяла на себе контроль за виконанням певної діяльності [12].

К. Муздибаєв вказує на зв'язок відповідальності особистості з усвідомленням нею змісту свого життя. Від мотивації, змісту та цінностей, які спонукають людину до діяльності, залежить активність особистості, усвідомлене ставлення до своєї діяльності «... чим більш очевидний для суб'єкта зміст його буття, тим більш відповідальними є його вчинки» [7, с. 128]. Відчуженість від соціальних норм і невміння знаходити сенс власного буття послаблюють активність та відповідальність особистості.

А. Колот переконаний, що відповідальність явище світоглядного характеру. Адже поширення конформізму, егоїзму, інших виявів соціальної безвідповідальності $\epsilon$ свідченням девальвації цінностей і установок, що визначають вектор соціально відповідальної поведінки [13].

М. Савчин вважає, що для функціонування відповідальності важливе значення мають моральні конструкти свідомості як специфічні засоби моральної інтерпретації реальності, крізь призму яких суб'єкт сприймає дійсність і себе у ній. Вчений виділяє такі основні сфери вияву відповідальної поведінки особистості: система «Я інші»; життєвиявлення та самоствердження «Я» (у праці, пізнанні, матеріальному житті); інші особи і групи (діти, родичі, сім'я тощо); функціонування, становлення і саморозвиток «Я» [5]. Тому вихідним положенням нашого дослідження стало розуміння відповідальності як системної властивості особистості, світоглядного феномену, що є результатом інтеграції іï суб'єктивного уявлення про світ і соціальну взаємодію, осмислення нею самої себе, оцінки власних ресурсів і вимірів взаємодії із соціальним середовищем, коли особистість усвідомлює себе творцем власної життєдіяльності.

Оскільки відповідальність є динамічним утворенням, тому у психологічній науці пильну увагу приділено особливостям iї розвитку. Зокрема, К. Муздибаєвим означено напрями розвитку відповідальності через зміну ії інстанцій: від відповідальності дитини перед дорослими до їі інтеріоризації - відповідальності перед собою, коли совість стає основним регулятором поведінки; від колективної - до індивідуальної; від зовнішньої до внутрішньої; від ретроспективного плану - до перспективного [7].

У дослідженні K. Helkam розкрито послідовність змін критеріїв відповідальності: конформність стосовно зовнішніх правил; особисті мотиви дій, незалежність поведінки індивіда від впливу оточуючих; почуття обов'язку, свободи; усвідомлення соціальних норм і правил поведінки у відповідності із власними мотивами та намірами, 3 
огляду на моральні переконання; незалежність і стійкість прийнятих людиною моральних принципів, що дає їй моральну автономію і можливість самостійного вибору рішень [10].

Проведені нами попередні емпіричні дослідження дозволяють стверджувати, що саме рефлексія як інтегрований процес, спосіб і механізм виходу системи психіки за власні межі істотно впливає на розвиток відповідальності особистості [14].

I. Степаненко зосереджує увагу на тому, що відповідальне ставлення до життя - це багатомірний і багатогранний феномен, фундаментом якого $\epsilon$ вимога продовження буття людини і як розумної, і як духовної істоти [15].

Якщо людина усвідомлює духовний вимір свого існування, живе по совісті, іiі моральність комплексно виявляється в екзистенційній відповідальності. Така відповідальність є вагомим складником духовності особистості, яка бажає і здатна автентично, внутрішньо-психічно обирати значущі для неї духовні цінності та неухильно діяти, відповідно до них [16]; є необхідним особистісним утворенням завдяки якому вона стає автономною - вільно функціонує в суспільстві, психологічно зростає через усвідомлення внутрішнього досвіду власної самості [9]; виконує функцію специфічного медіатора, який об'єднує професійні та особистісні властивості особистості, що самоактуалізується, сприяє стимуляції усвідомлення людиною потреби в метамотивації і руху до вищих цінностей буття, веде до внутрішньої трансформації, духовного зростання, що є вищою метою життєздійснення особистості [6]; є однією 3 головних особливостей автентичної особистості як символу оптимального функціонування і вдосконалення [8].

Отже, можна зробити висновок, що високий рівень розвитку відповідальності як феноменального світоглядного утворення особистості вказує на глибоке усвідомленням нею змісту свого життя через осмислення соціальної дійсність і себе у ній, здатність самостійно обирати значущі для неї духовні цінності та керуватися ними у своїй життєдіяльності. За таких обставин саме моральність, совість стають основним регулятором відповідальної поведінки.

Проведене емпіричне дослідження відповідальності майбутніх психологів i соціальних працівників як їх феноменального світоглядного утворення передбачало детальне вивчення особливостей усвідомлення студентами-першокурсниками вказаних спеціальностей сутності феномену відповідальності, усвідомлення досліджуваними іiі взаємозв'язку з іншими особистісними рисами, а також осмислення мотивів власної відповідальної поведінки та найбільш значущих сфери іï реалізації у процесі міжособистісної та внутрішньо групової взаємодії в різних формах життєдіяльності.

Дослідження проводилося на базі Інституту людини Київського університету імені Бориса Грінченка, факультету психології та факультету соціально-економічної освіти Національного педагогічного університету імені М. П. Драгоманова. Загальна вибірка досліджуваних склала 180 студентів перших курсів, із них 115 майбутніх психологів і 65 соціальних працівників. Для реалізації програми емпіричного дослідження було використано такі психодіагностичні методики: опитувальник "Дослідження мотиваиії відповідальної поведінки» (авт. М. Савчин), який містить 36 висловлювань, що об'єднуються у 9 груп мотивів відповідальної поведінки: 1) суспільних; 2) морального самоствердження; 3) прагматичних; 4) самореалізації; 5) самопізнання; 6) егоїстичного самоствердження; 7) неспецифічних; 8) спілкування; 9) виховання інших [5]; анкета "Особливості усвідомлення студентами відповідальності як професійно значущзӧ якості майбутнього фахівця» (авт. О. Патинок), спрямована на дослідження особливостей усвідомлення студентами поняття відповідальність та особливостей відповідальної поведінки [4]; методика «Визначення відповідальності» (авт. М. Осташева), яка містить 30 запитань та спрямована на вивчення міри розвитку видів відповідальності: дисциплінарної відповідальності, відповідальності за себе і відповідальності за інших [4].

Основне завдання першого етапу дослідження полягало у з'ясуванні особливостей розуміння студентами-першокурсниками сутності поняття «відповідальність» та усвідомлення іiі взаємозв'язку 3 іншими особистісними характеристиками. Дослідження здійснювалося за допомогою анкети О. Патинок. Як показав якісний аналіз узагальнених відповідей студентів, їхнє розуміння поняття відповідальності $€$ неоднозначним і характеризується широкою варіативністю. Зокрема, студенти задекларували такі варіанти трактування поняття «відповідальність»:

1. Свідоме прийняття рішення про виконання дій та готовність відповідати за їх наслідки (передбачення наслідків у випадку невиконання справи; розуміння проблем, які з'являться, якщу не виконати поставленої задачі; прийняття зобов'язання виконувати дії та відповідати за можливі наслідки цүих дій; свідоме ставлення людини до своєі роботи та здатність прогнозувати можливі наслідки ї̈ невиконання; оиінка своїх дій $i$ їx наслідків; готовність відповідати за свої вчинки тощзо - 30,4\% студентів.

2. Здатність людини дотримуватися норм (здатність людини аналізувати свої вчинки та 
чинити відповідно до маральних $i$ соціальних норм; здатність людини дотримуватися певних правил і усвідомлювати свої можливості тощзо) $17,3 \%$ студентів.

3. Свідоме прийняттям та виконання обов'язків (усвідомлення власних обов'язків; здатність людини брати на себе певні, доступні для виконання нею, обов'язки і вчасне раціональне їх виконання; розуміння людиною свого обов'язку, обіцянки чи доручення; бажання щзось зробити через почуття обов 'язку тощо) - 21,7\% студентів.

4. Риса характеру, яка виявляється у здатності доводити розпочату справу до логічного завершення, бути послідовним (риса характеру, відповідно до якої людина дотримується свого слова і виконує заплановані дї; здатність виконувати обічянки; здатність завершити справу тощуо) $13,4 \%$ студентів.

5. Розуміння людиною важливості виконання певних справ (усвідомлення важливості виконання задачі; усвідомлення необхідності виконання справи незалежно від ступеня ї складності, рівня мотивачії та особистих вподобань тощуо) - 8,6\% студентів.

6. Специфічне переживання, яке пов'язане 3 совістю (бути чесним перед самим собою; внутрішне бажання діяти по совісті; обов'язок перед самим собою; увага до потреб інших людей, внутрішня радість від допомоги іншому; добросовісне виконання роботи тощчо) - 8,6\% студентів.

Окрім варіантів трактування студентами поняття «відповідальність», на основі ранжування отриманих якостей було виокремлено групи особистісних характеристик, наявність яких, на думку першокурсників, впливає на здатність особистості до здійснення відповідальної поведінки (перераховуються в порядку зменшення значущості впливу на відповідальну поведінку особистості):

1. Група вольових якостей (вольова саморегуляція, впевненість у своїх словах і діях, вольові здібності, здатність до самоконтролю, здатність тримати себе в руках, самоорганізованість, самовладання, стриманість, пунктуальність).

2. Група лідерських якостей (рішучість, наполегливість, ініціативність, цілеспрямованість, сконцентрованість, хоробрість, сміливість, впевненість, принциповість).

3. Здатність до рефлексії та критичного мислення: розуміння ситуацій, здатність роздивитися проблему з різних сторін, здатність критично мислити, адекватна оцінка своїх можливостей, розуміння ризиків, розумність, поміркованість, незалежність суджень.

4. Моральні характеристики (любов до інших, повага до себе та своїх ближніх, зацікавленість у житті та людях, страх за чиєсь життя, товариськість, емпатійність, чуйність, щирість, відвертість, сумлінність, доброзичливість, щедрість, чесність, надійність).

5. Особистісна зрілість (добросовісність, совість, автентичність, самодостатність, мудрість).

Проведений аналіз дозволяє констатувати, що більшість першокурсників (як майбутніх психологів, так і соціальних працівників) розуміє відповідальність як вміння передбачати наслідки вчинків, усвідомлювати їх значущість; як зобов'язання, здатність дотримуватися норм і доводити справу до кінця, бути послідовним. Саме тому вони пов'язують відповідальність із вольовими та лідерськими характеристиками особистості, а також iї здатністю критично мислити. Незначна кількість першокурсників пов'язує відповідальність із моральністю особистості, іiі внутрішніми потребами, совістю, з духовним розвитком особистості.

Наступним завданням дослідження було вивчення мотивації відповідальної поведінки студентів-першокурсників, майбутніх психологів і соціальних працівників.

Як показав аналіз результатів дослідження, на першому курсі навчання у майбутніх психологів спостерігається така ієрархія мотивів відповідальності: перше рангове місие займають суспільні мотиви (середній показник 16,3), що виражаються у прагненні чинити відповідально для зобов'язання перед суспільством, а також у намаганні своєю поведінкою, конкретними вчинками принести користь рідним, близьким; друге - посідають мотиви самореалізації (середній показник 15,7), пов'язані з прагненням втілити свої вміння у конкретній справі (прагнення одержати задоволення від результатів роботи тощо), третє - мотиви самопізнання (середній показник 15,4), які виражаються у потребі пізнати себе (порівняти себе 3 іншими, усвідомити власні вміння і навички, перевірити силу волі та характер); четверте прагматичні мотиви (середній показник 15,1), які виявляються у намаганні розглядати свою поведінку, вчинки з точки зору користі насамперед для себе, використовувати свої вчинки для задоволення власних потреб; n'яте - мотиви спілкування (середній показник 14,7), в основі яких лежить потреба встановити чи зберегти стосунки 3 іншими, а також потреба духовного контакту 3 іншою людиною як цінністю; шосте - мотиви морального самоствердження (середній показник 14,2), які пов'язані з намаганням утвердити себе в статусі моральної особистості; сьоме - мотиви виховання інших (середній показник 13,2), що виражаються у необхідності бути прикладом для інших, впливати на їх поведінку; восьме - неспе- 
цифічні мотиви (середній показник 11,5), пов'язані зі страхом покарання за невиконане доручення, 3 намаганням уникнути критики, дев'яте місие посідають мотиви егоїстичного самоствердження (середній показник 10,8), пов'язані з намаганням привернути до себе увагу, показати свою перевагу над іншими.

У майбутніх соціальних працівників порівняно 3 майбутніми психологами найбільш значущі відмінності спостерігаються у вираженості мотиву морального самоствердження (який у соціальних працівників за ступенем вияву посідає третє рангове місце, тоді як у психологів цей мотив значно менш виражений - займає шосте рангове місце) та прагматичного мотиву (який більш виражений у майбутніх психологів - 4 рангове місце, проти 7-го місця у майбутніх соціальних працівників) (див. табл. 1).

Отже, можна зробити висновок, що для майбутніх психологів-першокурсників найбільш значущою сферою вияву відповідальності є система «Я-Я». Мотиви самореалізації, самопізнання та прагматичні мотиви, що виявляються у намаганні особистості бути відповідальною з точки зору користі насамперед для себе, займають домінуючі позиції.

Менш значущою сферою вияву відповідальності для майбутніх психологів є система «Я-інші». Так, хоча суспільні мотиви й займають перше рангове місце (де домінуючим є мотив обов'язку та намагання принести користь рідним, близьким), однак мотиви спілкування та морального самоствердження значно менше виражені порівняно 3 попередньою групою мотивів. Для майбутніх соціальних працівників порівняно 3 майбутніми психологами менш вираженою $є$ прагматична спрямованість мотивації відповідальності та більшої значущості набуває вияв відповідальності в системі «Я-інші».

Підтвердженням цих тенденцій стали результати наступного етапу дослідження, на якому ми вивчали особливості розвитку в майбутніх психологів і соціальних працівників різних видів відповідальності: дисииплінарної як нормативно-ціннісного ставлення особистості до суспільно-значущих справ, правил і вимог, особливості нормативної поведінки; відповідальності за себе, що дозволяє виявити рівень відповідальності студента через його ставлення до доручень, виконання власних обов'язків і розуміння необхідності їх виконання; відповідальності за іншого як переживання особистісної причетності майбутнього фахівця до долі інших людей, його готовність брати на себе відповідальність за інших (за методикою М. Осташевої). Отримані результати дослідження презентовані на рис. 1 .

Узагальнення виявлених тенденцій дозволяе стверджувати, що у майбутніх психологів серед видів відповідальності найбільш розвинена дисциплінарна відповідальність $(26,2)$, на другому місці за рівнем сформованості знаходиться відповідальність за себе $(25,3)$ і найменш розвинена відповідальність за іншого $(24,6)$. У соціальних працівників тенденції дещо інші: на першому місці, як і у майбутніх психологів, перебуває дисциплінарна відповідальність $(28,12)$, на другому відповідальність за інших $(27,53)$, на третьому відповідальність за себе $(23,54)$.

Отримані результати вказують на домінування у першокурсників дисциплінарної відповідальності як усвідомлення необхідності дотримання зовнішніх норм взаємодії та вимог викладачів як певної нормативної поведінки, а також на відмінності у баченнях майбутніми психологами та соціальними працівниками найбільш значущої сфери вияву відповідальності.

Висновки. Феномен відповідальності як базової світоглядної властивості особистості є результатом інтеграції ії суб'єктивного уявлення про світ і соціальну взаємодію в ньому, осмислення себе

Таблиця 1

Ієрархія мотивів відповідальності майбутніх психологів і соціальних працівників, $\mathbf{n}=180$

\begin{tabular}{|c|c|c|}
\hline \multirow[t]{2}{*}{ Перелік мотивів відповідальності } & $\begin{array}{c}\text { Студенти I курсу } \\
\text { (майбутні психологи) }\end{array}$ & $\begin{array}{c}\text { Студенти I курсу } \\
\text { (майбутні соціальні праців- } \\
\text { ники) } \\
\end{array}$ \\
\hline & \multicolumn{2}{|c|}{$\begin{array}{c}\text { Рангове місце мотиву в ієрархї̈ розвитку } \\
\text { відповідальності }\end{array}$} \\
\hline Самореалізації & 2 & 2 \\
\hline Самопізнання & 3 & 4 \\
\hline Суспільні & 1 & 1 \\
\hline Морального самоствердження & 6 & 3 \\
\hline Спілкування & 5 & 5 \\
\hline Виховання інших & 7 & 6 \\
\hline Прагматичні & 4 & 7 \\
\hline Неспецифічні & 8 & 8 \\
\hline Егоїстичного самоствердження & 9 & 9 \\
\hline
\end{tabular}




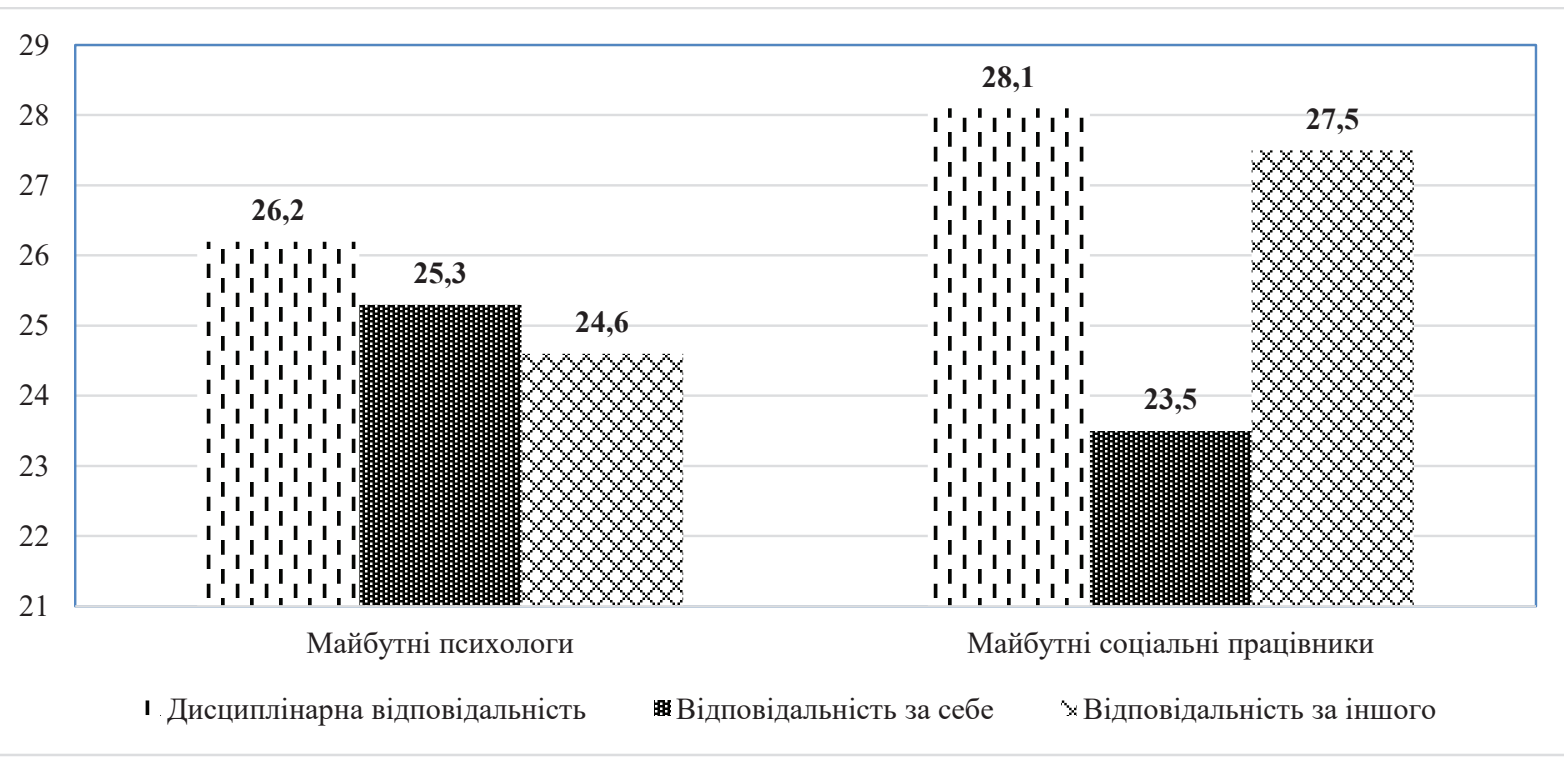

Рис. 1. Показники вияву видів відповідальності майбутніх психологів і соціальних працівників (середні показники)

в цьому світі та усвідомлення творцем власної поведінки у найбільш значущих для особистості сферах іiі життєдіяльності. Змістом високого рівня розвитку відповідальності є здатність особистості усвідомлювати та самостійно обирати значущі для неї духовні цінності та керуватися ними у своїй поведінці. За таких обставин саме совість стає основним регулятором відповідальної поведінки.

Констатовано, що лише 8,6\% студентів першого курсу пов'язує відповідальність із духовними цінностями, совістю. Домінуючим для першокурсників, майбутніх психологів і соціальних працівників $€$ розуміння відповідальності як вміння особистості передбачати наслідки вчинків та усвідомлювати ï значущість, свідоме прийняття та виконання обов'язків, здатність дотримуватися норм і доводити справу до кінця. Здебільшого першокурсники пов'язують відповідальність із вольовими та лідерськими характеристиками особистості, здатністю критично мислити, а моральні характеристики та показники особистісної зрілості займають тут останні рангові позиції. Серед видів відповідальності найбільш розвиненою є дисциплінарна.

Встановлено відмінності мотиваційної структури відповідальної поведінки у майбутніх психо- логів і соціальних працівників, а також ієрархію найбільш значущих сфер іiі реалізації. Так, для майбутніх психологів найбільш значущою сферою вияву відповідальності є система «Я-Я», для майбутніх соціальних працівників - система «Я-Інші»; відповідальність у майбутніх психологів має більш виражену егоцентричну спрямованість, зокрема, більш виражені мотиви самореалізації, самопізнання та прагматичні мотиви, тоді як у майбутніх соціальних працівників - мотиви спілкування та морального самоствердження. Очевидно, що такі відмінності зумовлені специфікою особистісних характеристик абітурієнтів, які обирають професію психолога чи соціального працівника, а також особливостями процесу їх професійної підготовки.

Виявлені тенденції зумовлюють необхідність пошуку шляхів і засобів цілеспрямованого формування відповідальності майбутніх фахівців у процесі їх професійної підготовки через спонукання студентів до більш виваженого аналізу внутрішніх чинників відповідальності, формування у них світоглядних орієнтирів на усвідомлення духовного виміру власного життя та розвиток духовного Я особистості, коли духовні цінності стають основним регулятором її поведінки.

\section{ЛІТЕРАТУРА}

1. Баранова С.В. Соціально-психологічні механізми формування професійної відповідальності колективних суб'єктів управління : дис. канд. псих. наук: 19.00.05. Луганськ, 2004. 225 с.

2. Гурлєва Т.С. Психолого-педагогічні умови формування відповідальності у важковиховуваних підлітків : дис. канд. психол. наук: 19.00.07. Київ, 2015. 285 с.

3. Палагнюк О.В. Потенціал християнських настановлень у контексті формування соціальної відповідальності особистості: науково-методичний аналіз. Науковий журнал «Молодий вчений». Херсон : ТОВ Видавничий дім «Гельветика», 2019. № 6 (70) червень. С. 96-102. 
4. Патинок О.П. Становлення відповідальності як професійно значущої якості соціального працівника : дис. канд. психол. наук: 19.00.07. Київ, 2008. 265 с.

5. Савчин М.В. Психологія відповідальної поведінки : [монографія]. Івано-Франковськ : Місто НВ, 2008. $280 \mathrm{c}$.

6. Маслоу А. Мотивация и личность. [пер. с англ. Т. Гутман, Н. Мухина]. СПб : Питер, 2003. 351 с.

7. Муздыбаев К. Психология ответственности / под ред. В.Е. Семенова. Изд. 2-е, доп. М. : ЛИБРОKOM, 2010. $248 \mathrm{c}$.

8. Перлз Ф. Гештальт-подход. Свидетель терапии. М. : Издательство Института Психотерапии, 2007. $224 \mathrm{c}$.

9. Роджерс К. Клиенто-центрированная терапия. [Пер. с англ]. М. : «Рефл-бук», К. : «Ваклер» 1997. $320 \mathrm{c}$.

10. Helkama K. Toward a cognitive-development altheory of attribution of responsibility. Helsinki, 1981. $212 \mathrm{~s}$.

11. Ананьев Б.Г. Человек как предмет познания. 3-е изд. СПб : Питер, 2010. 288 с.

12. Абульханова-Славская К.А. Типология активности личности. Психологический журнал. 1985. Т. 6. № 5. С. 3-18.

13. Колот А. Соціальна відповідальність людини як чинник стійкої соціальної динаміки: теоретичні засади. Україна: аспекти праці. 2011. № 3. С. 3-9.

14. Кутішенко В.П., Ставицька С.О. Рефлексія як метаздібність до вибудовування цілісності життя та успішності спілкування майбутніх фахівців. Актуальні проблеми психології : Збірник наукових пращь Інституту психологї̈ імені Г.С. Костюка НАПН України. Том VI: Психологія обдарованості. Київ-Житомир : Вид-во ЖДУ ім. I Франка, 2019. Випуск 15. С. 87-98.

15. Степаненко I. Відповідальне ставлення особистості до життя: структурно-функціональний вимір. Філософія освіти. 2006. № 1. С. 122-131.

16. Москалець В. Духовні горизонти особистості: потенціал вершинної аналітики. Психологія і суспільство. 2011. № 1. С. 73-84.

\section{REFERENCES}

1. Baranova S.V. (2004) Sotsialno-psykholohichni mekhanizmy formuvannia profesiinoi vidpovidalnosti kolektyvnykh subiektiv upravlinnia [Socio-psychological mechanisms of the formation of the professional responsibility of collective management entities] (PhD Thesis), Luhansk.

2. Hurlieva T.S. (2015) Psykholoho-pedahohichni umovy formuvannia vidpovidalnosti u vazhkovykhovuvanykh pidlitkiv [Psychological and pedagogical conditions for the development of responsibility of troubled adolescents] (PhD Thesis), Kyiv.

3. Palahniuk O.V. (2019) Potentsial khrystyianskykh nastanovlen v konteksti formuvannia sotsialnoi vidpovidalnosti osobystosti: naukovo-metodychnyi analiz [The strength of Christian guidelines in the context of developing an individual's social responsibility: a scientific and methodological analysis]. Naukovyi zhurnal "Molodyi vchenyi". Kherson : TOV Vydavnychyi dim "Helvetyka", № 6 (70), p. 96-102.

4. Patynok O.P. (2008) Stanovlennia vidpovidalnosti yak profesiino znachushchoi yakosti sotsialnoho pratsivnyka [Responsibility formation as professional important qualities of a social worker] (PhD Thesis), Kyiv.

5. Savchyn M.V. (2008) Psykholohiia vidpovidalnoi povedinky : monohrafiia [Responsible behavior psychology : a monograph]. Ivano-Frankovsk : Misto NV.

6. Maslou A. (2003) Motivatsiya i lichnost [Motivation and personality]. SPb : Piter.

7. Muzdybaev K. (2010) Psikhologiya otvetstvennosti [Responsibility psychology]. Izd. 2-e, dop. Moscow : LIBROKOM.

8. Perlz F. (2007) Geshtalt-podkhod. Svidetel terapii [Gestalt approach. Therapy evidence]. Moscow : Izdatelstvo Instituta Psikhoterapii.

9. Rodzhers K. (1997) Kliento-tsentrirovannaya terapiya [Client-centered]. Moscow : "Refl-buk", Kyiv : "Vakler".

10. Helkama K. (1981) Toward a cognitive-developmenal theory of attribution of responsibility. Helsinki.

11. Ananev B.G. (2010) Chelovek kak predmet poznaniya [A man as an object of cognition ]. 3-e izd. SPb : Piter.

12. Abulkhanova-Slavskaya K.A. (1985) Tipologiya aktivnosti lichnosti [Typology of personal activity]. Psikhologicheskiy zhurnal, vol. 6, № 5, p. 3-18.

13. Kolot A. (2011) Sotsialna vidpovidalnist liudyny yak chynnyk stiikoi sotsialnoi dynamiky: teoretychni zasady [Social responsibility of a man as a factor of the stable social dynamics: theoretical principles]. Ukraina: aspekty pratsi, № 3, p. 3-9. 
14. Kutishenko V.P., Stavytska S.O. (2019) Refleksiia yak metazdibnist do vybudovuvannia tsilisnosti zhyttia ta uspishnosti spilkuvannia maibutnikh fakhivtsiv [Reflection as a meta-capacity for constructing the integrity of life and successful communication of the future specialists]. Aktualni problemy psykholohii : Zbirnyk naukovykh prats Instytutu psykholohii imeni H.S. Kostiuka NAPN Ukrainy. Tom. УI: Tom UI: Psykholohiia obdarovanosti. Kyiv-Zhytomyr : Vyd-vo ZhDU im. I Franka, vol. 15, p. 87-98.

15. Stepanenko I. (2006) Vidpovidalne stavlennia osobystosti do zhyttia: strukturno-funktsonalnyi vymir [Person's responsible attitude towards lifw: a structural-functional dimension ]. Filosofiia osvity, № 1, p. $122-131$.

16. Moskalets V. (2011) Dukhovni horyzonty osobystosti: potentsial vershynnoi analityky [Spiritual horizons of a personality: potential of upper analytics]. Psykholohiia $i$ suspilstv, № 1, p. 73-84. 